Dept. of Poultry Diseases

Animal Health Research Institute, Ismailia

\title{
STUDIES ON CHICKENS ORNITHOBACTERIUM INFECTION AT ISMAILIA PROVINCE
}

(With 6 Tables and 8 Figures)

\author{
By \\ M.K. MOURSI and KAWTHER H. SABAH* \\ * Dept of Bacteriology, Animal Health Research Institute, Ismailia,
}

(Received at 22/1/2008)

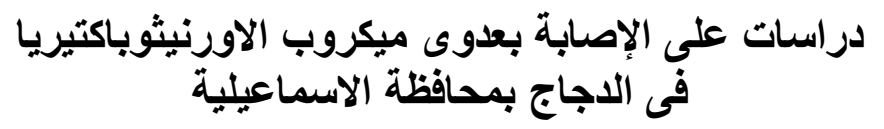

محمد كمال مرسي دسوقى ، كوثر حسين احمد

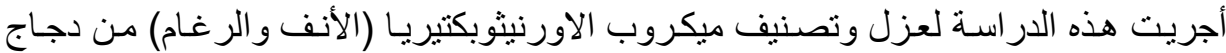

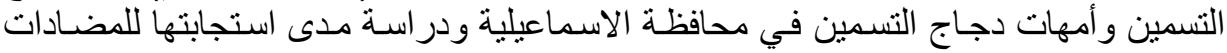

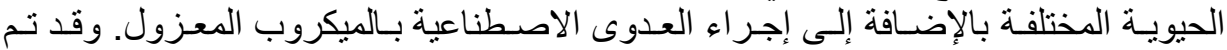

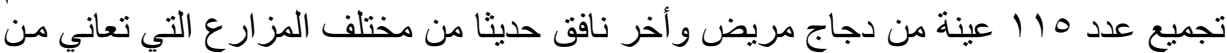

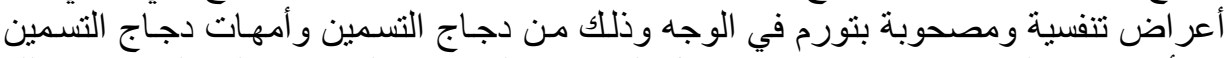

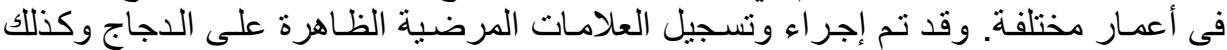

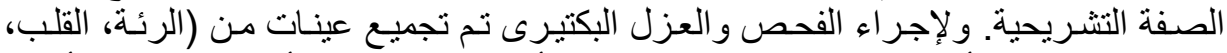

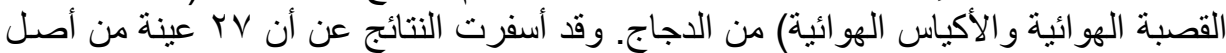
110

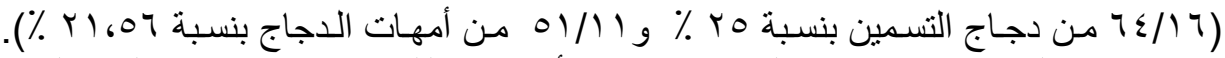

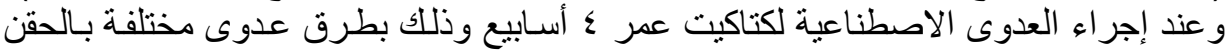

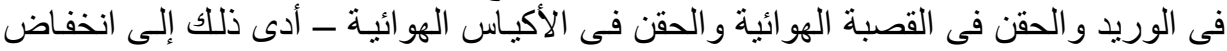

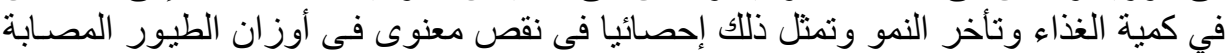

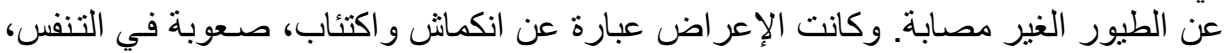

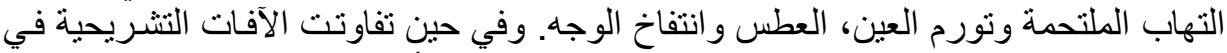

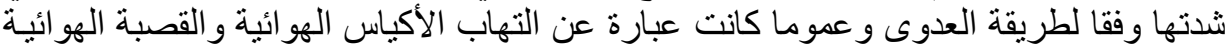

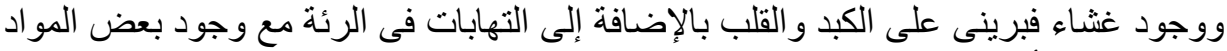

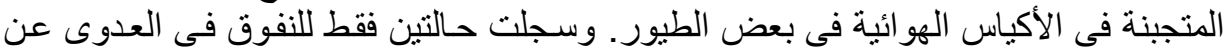

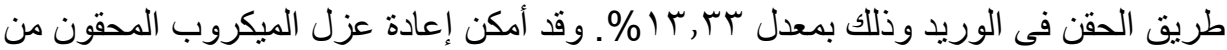

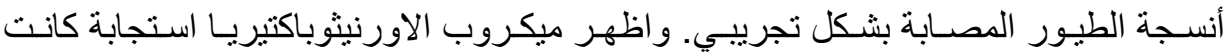

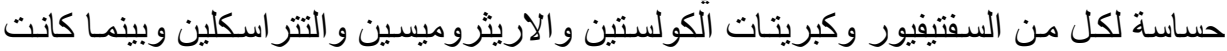

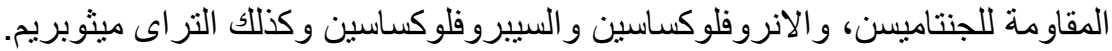

\section{SUMMARY}


A total of 115 diseased and freshly dead broilers and broiler breeders' chickens were collected from different farms at different ages. They were suffering from respiratory signs and facial swelling. Complete clinical and postmortem examinations were recorded. Samples from lung, heart, trachea and air sacs were collected for bacteriological isolation. Antibiotic sensitivity test as well as experimental infection were applied. The results showed that 27 out of $115(23.47 \%)$ were positive for isolation of $O$. rhinotracheale (16/64 from broilers $25 \%$ and $11 / 51$ from broiler breeders $21.56 \%$ ). Experimental infection of 4 weeks old chickens via intravenous, intra-tracheal and intra-air-sac leads to decrease in feed intake and growth retardation (The mean of body weight in all infected groups were significantly $(\mathrm{P}<0.05)$ lower than control group, depression, ruffling difficult breathing, conjunctivitis, sneezing, nasal discharge followed by facial edema. Postmortem lesions varied in severity according to inoculated routes and generally were tracheitis, arisaculitis, pneumonia, pericarditis, and perihepatitis, caseated material in air sac of some birds and arthritis. $O$. rhinotracheale could be reisiolated from affected organs of experimentally infected birds. Mortality was recorded in two birds only (13.33\%) after intravenous inoculation. The isolated $O$. rhinotracheale were sensitive to amoxicillin, ceftiofur colstin sulphate, erythromycin and tetracycline while were resistant to gentamycin, enrofloxacin, ciprofloxacin and trimethoprim.

Key words: Ornithobacterium O. rhinotracheale, broilers, antibiotic sensitivity

\section{INTRODUCTION}

Respiratory infections are still a major problem in poultry and accompanied by heavy economic loss due to increase mortality, increase medication costs, increase condemnation rates, drops in egg production, reduction of egg shell quality and decrease hatchability (Van Epmel and Hafez, 1999).

Since December 1991 respiratory manifestation with different clinical courses have been observed in poultry flocks in different countries (Charlton et al., 1993; Hafez et al., 1993; Hinz et al., 1994; Van Beek et al., 1994). It was initially regarded as pasteurella like organism and finally $O$. rhinotracheale has been proven to be the primarily pathogen in broiler (Van Veen et al., 2000 a \& b). The organism has been isolated from the partridge, pheasant, pigeon, rook, quail duck, ostrich, goose, guinea fowl, chicken and turkey (Charlton et 
al., 1993; Vandamme et al., 1994 and van Empel et al., 1999). $O$. rhinotracheale (ORT) is a Gram-negative, non-motile, pleomorphic, rod-shaped, non-spore forming bacterium. Most strains grow under aerobic, micro-aerophilic, and anaerobic conditions. Optimal growth occurs on 5\% sheep blood agar (Van Empel and Hafez, 1999).

Ornithobacterium rhinotracheale infection is an acute highly contagious disease of chickens and turkeys. The severity of clinical signs, duration of the disease and mortality are extremely variable and are influenced by many environmental factors such as poor management, inadequate ventilation, high stocking density, poor litter conditions, poor hygiene, high ammonia level, concurrent diseases and the type of secondary infection (Hafez, 1996). It is very sensitive to antibiotics and chemical disinfectants (Hafez and Schulze, 1998) but it can acquire resistance against antibiotic easily (Van Emple, 1998), Currently Ornithobacterium rhinotracheale infections may be appeared to become an endemic features, since it can affect every new restocking even in previously cleaned and disinfected houses especially in areas with intensive poultry production with multiple age farms (Hafez, 1996, Van Empel and Hafez, 1999).

$O$. rhinotracheale were able to induce the same kind of respiratory inflammations and weight-gain losses in chickens as well as turkeys after experimental infection Maja et al. (2006a) and Van Empel et al. (1996).

This study aimed to:

- Isolation and identification of $O$. rhinotracheale and its incidence in broilers and broilers breeders at Ismailia governorate.

- Experimental infection of isolated bacteria to susceptible chicks via different routes.

- Investigation of antibiotic sensitivity test of isolated bacteria to some chemotherapeutic agents.

\section{MATERIALS and METHODS}

\section{Birds and Samples:}

A total No. of 115 (64 broilers and 51 broilers breeders' chickens) were collected from different farms at Ismailia province, they were suffering from respiratory signs and facial swelling. Besides decreased eggs production in broiler breeders. Birds were subjected for clinical and postmortem examinations. Samples from lung, heart, trachea and air sacs were collected for bacteriological isolation.

\section{Bacteriological examination:}




\section{Bacterial isolation:}

Lungs, heart, trachea and tracheal swabs were inoculated into brain heart infusion broth supplemented with gentamycin as $5-10 \mu \mathrm{g} / \mathrm{ml}$ and incubated at $37^{\circ} \mathrm{c}$ for $24-48 \mathrm{hr}$., under 5\% CO2 tension by using gas bags in candle jar. Then loopfull from cultured broth were streaked on Blood agar with 7\% sheep blood either supplemented with gentamycin $10 \mu \mathrm{g} / \mathrm{ml}$ (to inhibit other bacterial growth) or without gentamycin and on MacConkey Agar. The plates were incubated at $37^{\circ} \mathrm{C}$ under aerobic conditions as well as at $37^{\circ} \mathrm{C}$ under anaerobic conditions in 5\% $\mathrm{CO}_{2}$ enriched environment by using gas bags in candle jar for 2-3 days according to Vandamme et al. (1994) Traverse et al. (1996) and Rojs et al. (2000).

\section{Identification:}

All suspected colonies were subjected for identification by colonial morphology (shape- colour- size- odour) and films were stained by gram stain and conventional biochemical tests were also applied (Van Empel et al., 1997).

\section{Biochemical characterization:}

ORT isolates were subjected to standard biochemical tests, including catalase, indole, motility, hydrogen sulfide, carbohydrates fermentations, phenylalanine deaminase, Lysine decarboxylase, $\beta$-Galactosidase, Ornithine decarboxylase methyl red, Voges Proskauer, citrate, urease and gelatine liquefaction, described by (Van Empel et al., 1997).

\section{In vitro sensitivity test:}

Determination of in vitro sensitivity pattern of the isolated organism against different chemotherapeutic discs were done. Interpretation of the results of susceptibility findings was done according to a standard protocol for antibiotic sensitivity tests described by the National Committee for Clinical and Laboratory Standards (NCCLS, 2002) and Malik et al. (2003).

\section{Pathogenicity test:}

Fifty six, days-old healthy chickens were used and reared at hygienic conditions, food and water were available ad libitum. By the age of 4 weeks; five randomly selected birds were sacrificed and bacteriologically tested before experiment to prove that they were free from ORT. The other birds (60) were divided into 4 groups each of 15 and housed separate as follow:

Group 1: chickens were inoculated intravenously with $1 \mathrm{ml}$ of a whole culture of brain heart infusion broth adjusted to account of 
approximately $1 \times 10^{7}$ colony forming units $/ \mathrm{ml}$ according to Saeb et al. (2002).

Group 2: chickens were inoculated intra-air-sac with $1 \mathrm{ml}$ of inoculum of ORT according to Saeb et al. (2002).

Group 3: chickens were inoculated intratracheally with $1 \mathrm{ml}$ of a whole culture of brain heart infusion broth adjusted to account of approximately $1 \times 10^{7}$ colony forming units $/ \mathrm{ml}$ according to Saeb et al. (2002).

Group 4: chickens non-inoculated and served as control.

Parameters of infection: During 7 to 14 days after 0 . rhinotracheale challenge, morbidity and mortality were recorded, the daily weight gain after challenge was determined, macroscopical lesions were recorded at postmortem examination of the birds, and attempts to reisolate the challenge bacteria were carried out. At postmortem examination, a scoring system for the observed lesions was used according to (Van Veen et al., $2000 \mathrm{a} \& \mathrm{~b}$ ) as follows:

\section{For air sacs:}

$0=$ no abnormalities

$1=$ one air sac seriously affected by fibrinous airsacculitis or limited pin-head sized foci of fibrinous exudate in both air sacs

2 = both air sacs seriously affected by fibrinous airsacculitis;

For lungs:

$0=$ no abnormalities

$1=$ unilateral pneumonia

$2=$ bilateral pneumonia.

\section{For trachea:}

$0=$ no abnormalities.

$1=$ some exudates in the tracheal lumen

$2=$ lumen of the trachea filled with exudates.

Statistical analysis: The statistical analyses for the weights and weight gains were performed by using Student's $t$-test (Snedecor \& Cochran, 1967).

\section{RESULTS}

Clinically affected bird showed depression, roughled feathers, decreased feed intake, reduce weight gain, sneezing, nasal discharge and facial edema. while the postmortem examination revealed uni- or bilateral consolidation of the Lungs fibrinous pericaditis airsacullitis tracheitis in some cases swelling of the liver and spleen

\section{Bacterial examination:}


Small pinpoint grey colonies, sometimes with a reddish glow, non hemolytic varied in diameter were observed after 24 or $48 \mathrm{hr}$ of incubation on blood agar. Growth was observed under both aerobic or microaerophilic conditions. No growth on MacConkey agar was seen. All isolates were gram negative, pleomorphic, rod-shaped bacteria.

Biochemical and enzymatic results obtained with routine laboratory reagents were uniform among isolates, showing oxidase positive, ferments glucose, lactose, galactose and fructose but doses not ferment sucrose and maltose. It was negative for catalase, methyl red, voges proskauer, gelatin liquefaction, citrate utilization, indole, nitrate reduction and triple sugar iron (Table 2). According to the cellular and colonial morphology of the organism and based on biochemical and enzymatic characteristics, by laboratory procedures, all isolates were identified as $O$. rhinotracheale.

The incidence of $O$. rhinotracheale isolation was $23.47 \%$ from the total examined samples of (lung, trachea, airsac). 27 out of 115 were positive for isolation of $O$. rhinotracheale (16/64 from broilers $25 \%$ and 11/51 from broiler breeders $21.56 \%$ ) as shown in Table (1). Table (3) showed the results of antibiotic sensitivity test of isolated O. rhinotracheale.

\section{Experimental studies:}

The most prominent clinical signs $1^{\text {st }} \& 2^{\text {nd }}$ weeks after experimental infection appeared to be decreased feed intake and growth retardation (The mean of body weight in all infected groups were significantly $(\mathrm{P}<0.05)$ lower than control group) Table $(6)$, depression, ruffling difficult breathing, mild conjunctivitis, sneezing, nasal discharge lacrimation followed by facial edema (Fig. 1), unilateral swelling of infraorbital sinuses (Fig. 2).

Post-mortem lesions were tracheitis, uni or bilateral pneumonia (Fig. 3), airsacculitis, slightly congested and enlarged liver \& spleen, fibrinous airsacculitis, tracheal exudates, fibrinous percarditis \& perhepatitis (Fig. 4), accumulation of fibrin and caseated materials in abdominal cavity (Fig. 5), patchy areas of fibrin on lungs surface. Some variations in signs and postmortem lesions were found between the inoculated routes (Table $4 \& 5$ ). Moreover I/V inoculation resulted in airsaculitis, pneumonia and severe arthritis in some birds and the bird could not stand (Fig. 6). The inoculated bacteria could be reisolated at day 7 postinoculation from the heart, liver, spleen, air sacs, and lung (Table 4). 
The intratracheal challenge resulted in airsacculitis, hydropericardium, pneumonia and mild arthritis. The inoculated bacteria could be reisolated from the trachea, lung, and air sac of inoculated chickens (Table 5).

The intra-air sacs challenge resulted in severe airsacculitis, accumulation of fibrin in abdominal cavity, pericarditis, perihepatitis, liver and heart adhesion. Bacteria were reisolated from the heart, lung, and air sac (Table 5). The mortality rate was recorded only in two birds $(13.33 \%)$ after $\mathrm{I} / \mathrm{V}$ inoculation. No deaths were observed in other groups.

Table 1: Incidence of $O$. rhinotracheale isolation from different examined flocks.

\begin{tabular}{|c|c|c|c|c|c|c|c|}
\hline \multirow{3}{*}{$\begin{array}{l}\text { Flock } \\
\text { no. }\end{array}$} & \multirow{3}{*}{ Type } & \multirow{3}{*}{ Age } & \multirow{3}{*}{$\begin{array}{c}\text { No. Of } \\
\text { examined } \\
\text { Samples }\end{array}$} & \multicolumn{4}{|c|}{ Results of isolation } \\
\hline & & & & \multicolumn{2}{|c|}{ Positive } & \multicolumn{2}{|c|}{ Negative } \\
\hline & & & & No & $\%$ & No & $\%$ \\
\hline 1 & Broilers & 4 weeks & 20 & 5 & 25 & 15 & 75 \\
\hline 2 & Broilers & 5 weeks & 23 & 6 & 26.08 & 17 & 73.92 \\
\hline 3 & Broilers & 6 weeks & 21 & 5 & 23.80 & 16 & 76.20 \\
\hline 4 & Broiler breeders & 25 weeks & 17 & 4 & 23.52 & 13 & 76.47 \\
\hline 5 & Broiler breeders & 30 weeks & 18 & 3 & 16.66 & 15 & 83.34 \\
\hline 6 & Broiler breeders & 34 weeks & 16 & 4 & 25 & 12 & 75 \\
\hline \multicolumn{3}{|c|}{ Total } & 115 & 27 & 23.47 & 88 & 76.53 \\
\hline
\end{tabular}

Table 2: Biochemical prosperities of isolated $O$. rhinotracheale

\begin{tabular}{|l|c|}
\hline \multicolumn{1}{|c|}{ Test Reaction } & Result \\
\hline Oxidase & + \\
\hline Catalase & - \\
\hline Nitrate reduction & - \\
\hline Indole & - \\
\hline Growth on MacConkey & - \\
\hline Arginine dehydrolase & + \\
\hline Lysine decarboxylase & - \\
\hline$\beta$-Galactosidase & + \\
\hline Ornithine decarboxylase & - \\
\hline Phenylalanine deaminase & - \\
\hline Urease & + \\
\hline Voges Proskauer & + \\
\hline Acidfrom carbohydrates: & +- \\
\hline Glucose & + \\
\hline Mannose & + \\
\hline Lactose & + \\
\hline Sucrose & - \\
\hline Sorbitol & + \\
\hline Maltose & - \\
\hline Dulcitol & + \\
\hline Fructose & \\
\hline
\end{tabular}


Table 3: In vito sensitivity test of $O$. rhinotracheale

\begin{tabular}{|l|c|l|l|l|l|}
\hline \multirow{2}{*}{ Antimicrobial disk } & \multirow{2}{*}{$\begin{array}{c}\text { Antibiotic } \\
\text { disc/conc. }(\mu \mathrm{g})\end{array}$} & \multicolumn{4}{|c|}{ Sensitivity of ORT } \\
\cline { 3 - 6 } & & \multicolumn{2}{|c|}{$\mathrm{S}$} & \multicolumn{2}{|c|}{$\mathrm{R}$} \\
\cline { 3 - 6 } & $($ Enr)-10 $\mu \mathrm{g}$ & $10 / 27$ & 37 & $17 / 27$ & 63 \\
\hline Enrofloxacin & $(\mathrm{Cip})-5 \mu \mathrm{g}$ & $11 / 27$ & 40.74 & $16 / 27$ & 59.26 \\
\hline Ciprofloxacin & Gn- $10 \mu \mathrm{g}$ & $0 / 27$ & 0.0 & $27 / 27$ & 100 \\
\hline Gentamycin & $\mathrm{N}-15 \mu \mathrm{g}$ & $14 / 27$ & 51.85 & $13 / 27$ & 48.15 \\
\hline Neomycin & $\mathrm{E}-15 \mu \mathrm{g}$ & $25 / 27$ & 92.59 & $2 / 27$ & 7.41 \\
\hline Erythromycin & $\mathrm{CT}-30 \mu \mathrm{g}$ & $24 / 27$ & 88.88 & $3 / 27$ & 11.12 \\
\hline Ceftiofur & $\mathrm{Col}-10 \mu \mathrm{g}$ & $27 / 27$ & 100 & $0 / 27$ & 0.0 \\
\hline Colistin sulphate & $\mathrm{TE}-30 \mu \mathrm{g}$ & $26 / 27$ & 96.29 & $2 / 27$ & 3.71 \\
\hline Tetracycline & $\mathrm{AM}-10 \mu \mathrm{g}$ & $27 / 27$ & 100 & $0 / 27$ & 0.0 \\
\hline Amoxycillin & $\mathrm{P}-10 \mu \mathrm{g}$ & $16 / 27$ & 59.25 & $10 / 27$ & 40.75 \\
\hline Penicillin G. & $\mathrm{SXT} 25 \mu \mathrm{g}$ & $9 / 27$ & 33.33 & $18 / 27$ & 66.67 \\
\hline $\begin{array}{l}\text { Trimethoprime / } \\
\text { Sulphamethoxazol }\end{array}$ & & & & & \\
\hline
\end{tabular}

Table 4: The pathological score lesion of experimentally infected chicks with $O$. rhinotracheale

\begin{tabular}{|c|c|c|c|c|}
\hline \multirow{2}{*}{ Route of inoculation } & \multirow{2}{*}{$\mathrm{N}$} & \multicolumn{3}{|c|}{ Pathologic lesions scores } \\
\cline { 3 - 5 } & & Air sac & Trachea & Lung \\
\hline Intravenous & 15 & 1 & 0 & 2 \\
\hline Intratracheal & 15 & 2 & 2 & 1 \\
\hline Intra-air-sac & 15 & 2 & 1 & 0 \\
\hline Control & 15 & 0 & 0 & 0 \\
\hline
\end{tabular}

Table 5: The postmortem lesions observed 2wk post-experimental infection via three inoculation routes with $O$. rhinotracheale $(\mathrm{ORT})$ and their reisolation.

\begin{tabular}{|c|c|c|c|c|c|c|c|c|c|c|c|c|}
\hline \multirow{2}{*}{$\begin{array}{l}\text { Route of } \\
\text { infection }\end{array}$} & \multirow{2}{*}{$\begin{array}{l}\text { No. of } \\
\text { chickens }\end{array}$} & \multicolumn{5}{|c|}{ Postmotem findings } & \multicolumn{6}{|c|}{ Reisolation at end of experiment } \\
\hline & & $\mathrm{A} / \mathrm{S}$ & $\mathrm{P}$ & $\mathrm{Ar}$ & HP & $\mathrm{PH} / \mathrm{PC}$ & Airsac & lung & Trachea & Heart & Liver & Spleen \\
\hline Intravenous & 15 & 4 & 7 & 3 & 0 & 2 & + & + & - & + & + & + \\
\hline Intratracheal & 15 & 9 & 3 & 0 & 2 & 1 & + & + & + & - & - & - \\
\hline Intra-air-sac & 15 & 7 & 0 & 0 & 1 & 7 & + & - & + & + & + & - \\
\hline Control & 15 & 0 & 0 & 0 & 0 & 0 & 0 & 0 & 0 & 0 & 0 & 0 \\
\hline
\end{tabular}

$\mathrm{A} / \mathrm{S}=$ airsacculitis; $\mathrm{P}=$ pneumonia; $\mathrm{Ar}=$ arthritis, swollen joint with caseous material; $\mathrm{HP}=$ hydropericardium; $\mathrm{PH} / \mathrm{PC}=$ fibrinous perihepatitis and pericarditis with adhesions . 
Table 6: The effect of $O$. rhinotracheale infection on average body weight and average daily weight gain.

\begin{tabular}{|c|c|c|c|c|c|}
\hline Route of inoculation & \multirow{2}{*}{$\begin{array}{c}\text { No. of } \\
\text { chickens }\end{array}$} & \multicolumn{3}{|c|}{ Body weight } & $\begin{array}{c}\text { Average daily } \\
\text { weight gain } \\
\text { between 21-35 }\end{array}$ \\
\cline { 3 - 6 } & & Day 21 & Day 28 & Day 35 & $30( \pm 5)^{\mathrm{c}}$ \\
\hline Intravenous & 15 & $845( \pm 60)$ & $1080( \pm 76)^{\mathrm{b}}$ & $1295( \pm 122)^{\mathrm{c}}$ & $35( \pm 1)^{\mathrm{c}}$ \\
\hline Intratracheal & 15 & $805( \pm 81)$ & $1085( \pm 85)^{\mathrm{b}}$ & $1330( \pm 127)^{\mathrm{c}}$ & $35)^{\mathrm{b}}$ \\
\hline Intra-air-sac & 15 & $815( \pm 109)$ & $1120( \pm 132)^{\mathrm{b}}$ & $1400( \pm 130)^{\mathrm{b}}$ & $39( \pm 2)^{\mathrm{b}}$ \\
\hline Control & 15 & $795( \pm 120)$ & $1160( \pm 91)^{\mathrm{a}}$ & $1575( \pm 103)^{\mathrm{a}}$ & $52( \pm 8)^{\mathrm{a}}$ \\
\hline
\end{tabular}

Within columns, averages having different letter are significantly different $(P<0.05)$

\section{LIST OF FIGURES}

Fig. 1: Conjunctivitis, lacrimation and facial edema of experimentally infected birds.

Fig. 2: experimentally infected chicks showed swelling of the infraorbital sinus accompanied by swollen head.

Fig. 3: Lung pneumonia in 4 weeks old broiler showing clear boundary between affected and non affected parts of the lung.

Fig. 4: Fibrinous pericarditis, perihepatitis and heart adhesion in experimentally infected chicks.

Fig. 5: Airsacculitis of abdominal air sac with accumulation of yellow caseous materials in abdominal cavity.

Fig. 6: Airsacculitis of thorasic air sac with large clots of fibrin experimentally infected chicks.

Fig. 7: Experimentally infected chicks showed legs affection, apart away and could not stand.

Fig. 8: Heart experimentally infected chicks showing fibrionus pericarditis. 
Assiut Vet. Med. J. Vol. 54 No. 117 April 2008
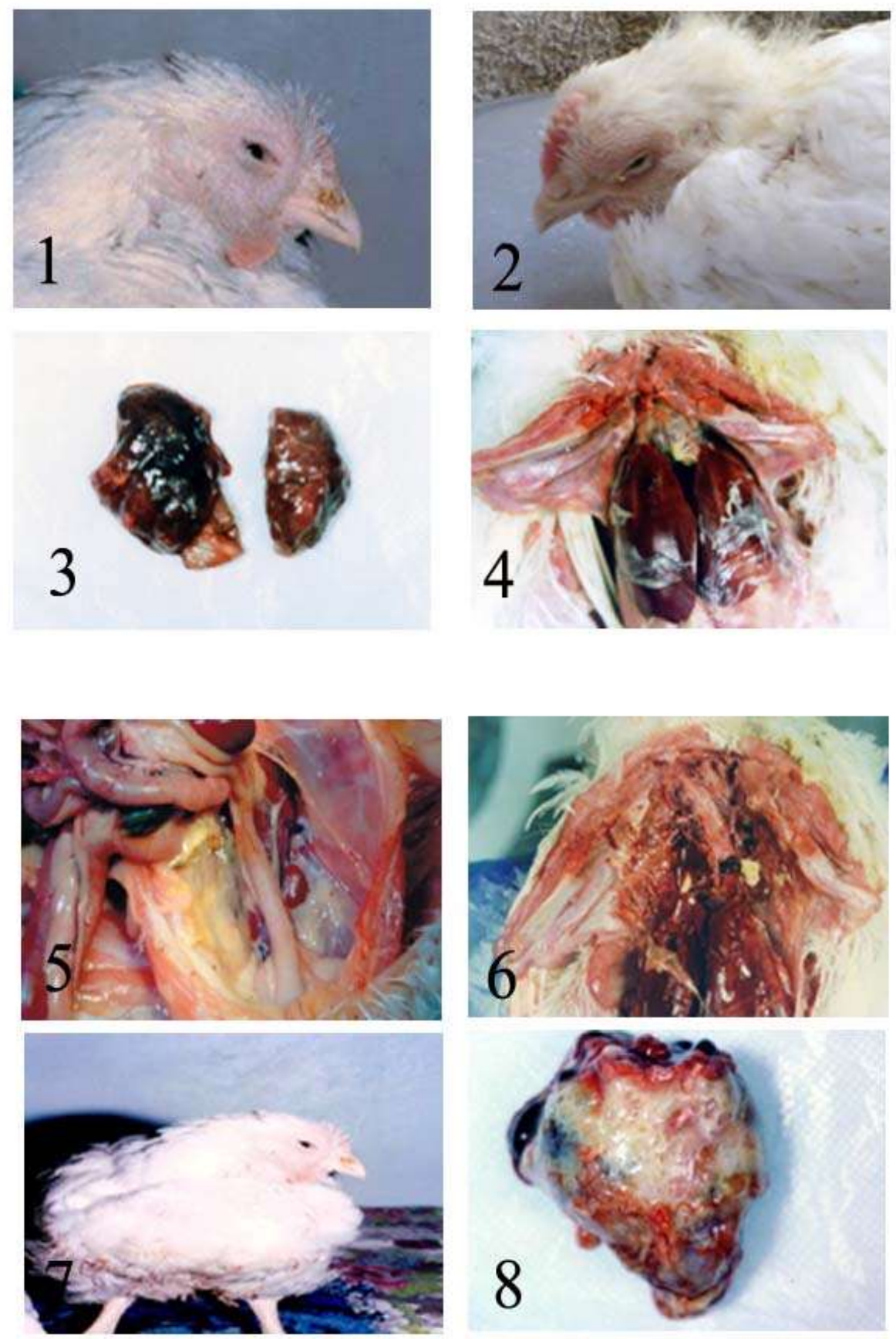


\section{DISCUSSION}

Respiratory disease conditions due to bacterial and viral agents are continuing to cause heavy economic losses in the poultry industry worldwide. Ornithobacterium rhinotracheale has been recognized in many countries worldwide and incriminated as a possible additional causative agent in respiratory disease complex. (Hafez, 2002).

In this study the clinical signs of naturally affected birds were depression, roughled feather, decreased feed intake, reduced weight gain, sneezing, nasal discharge and facial edema while the gross lesions in general were severe pneumonia, airsaculitis, tracheitis, oedema, unior bilateral consolidation of the lungs with fibropurulent exudates, pericarditis, airsacculitis, peritonitis. These findings are similar to those reported by Hafez, (2002) and Soriano et al. (2002)

Bacteriological examination revealed that the isolation of Small pinpoint grey colonies, sometimes with a reddish glow, non hemolytic varied in diameter were observed after 24 or $48 \mathrm{hr}$ of incubation on blood agar. All isolates were gram negative, pleomorphic, rod-shaped bacteria showing oxidase positive, ferments glucose, lactose, galactose and fructose but doses not ferment sucrose and maltose and for other tests it was negative for catalase, methyl red, voges proskauer, gelatin liquefaction, citrate utilization, indole, nitrate reduction and triple sugar iron.

All isolates could be identified as $O$. rhinotracheale by bacteriological laboratory tests. This result was completely agreed with biochemical and enzymatic properties of $O$. rhinotracheale reported by Charlton et al. (1993), Van Empel et al. (1997) Soriano et al. (2002) and Canal et al. (2005).

Ornithobacterium rhinotracheale was isolated from lung, air sac and trachea of examined birds as that reported by Saeb et al. (2002) and Soriano et al. (2002).

The incidence of $O$. rhinotracheale isolation in this study was $23.47 \%$ (27/115) from total examined samples (16/64 from broilers, $25 \%$ and $11 / 51$ from broiler breeders, $21.56 \%$ ) this result is much less than that reported by Abden and lotfy (2006) they reported that $O$. rhinotracheale was isolated by $75 \%$ of total examined chicks while, Shahata et al. (2006) isolated O. rhinotracheale at 34\% from lung, trachea and air sac of examined chickens and layers. In contrast Shihata and Ibrahium (2004) isolated $O$. rhinotracheale by $11.72 \%$. while Saeb et al. (2002) recoverd $O$. rhinotracheale by $8.8 \%$. Also Türkyilmaz, 
(2005) isolated $O$. rhinotracheale from broiler breeders of 37, 42 and 46 week old by $1.2 \%$.

Since a standard protocol for antibiotic sensitivity tests for $O$. rhinotracheale does not exist we depended upon the method described by the Clinical and Laboratory Standards Institute (CLSI, 2002) for fastidious Gram-negative organisms.

With regard to antibiotic sensitivity testing, the isolated $O$. rhinotracheale were sensitive to amoxicillin, ceftiofur colstin sulphate, erythromycin and tetracycline while were resistant to gentamycin, enrofloxacin ciprofloxacin and trimethoprim. This results are in agreement with these reported by Malik et al. (2003), Türkyilmaz, (2005) and Maja et al. (2007). Maja et al. (2006 a) reported that Acquired fluoroquinolone resistance is commonly encountered in ORT isolates. On the other hand, Shahata et al. (2006) found that amoxicillin, tetracycline and enrofloxacin were the most effective drugs against isolated ORT in vitro. Moreover, Saeb et al. 2002, found that $O$. rhinotracheale isolates were sensitive to tetracycline and to lesser extent to other antibiotics. Such differences in the antibiotic susceptibility pattern may be due to misuse and /or frequent exposure of the bacteria to antibiotics in field.

The results of experimental infections of $O$. rhinotracheale revealed that the three inoculated routes resulted in growth retardation, depression, ruffling, difficult breathing, conjunctivitis, sneezing, nasal discharge, lacrimation followed by facial edema, unilateral swelling of infraorbital sinuses. These results are in agreement with the studies of Travers et al. (1996) and Saeb et al. (2002) .Van Empel et al. (1996) reported that the most prominent clinical signs after experimental infection appeared to be the growth retardation, dyspnoea, mucus discharge and mortality.

In this study mortality was recorded in only two birds $(13.33 \%)$ after an intravenous injection with $O$. rhinotracheale. Goovaerts et al. (1998) found that only an intravenous challenge was able to induce $20 \%$ mortality in experiemntally $O$. rhinotracheale chicks, while Shahata et al. (2006) observed that the mortality was 30\% in experimentally infected birds. Also Shihata and Ibraheem (2004) found that moralities were $10 \%$ and $20 \%$ in hubbard and balady chicks respectively after experimental infection.

The result of gross lesion revealed development of different records of postmortem findings post-experimental infection via three inoculation routes. These findings were airsacculitis, pneumonia and 
pericarditis perihepatitis, and liver and heart adhesion and joint affection which are in agreement with the results obtained when similar inoculation routes were applied by Saeb et al. (2002) and Shahata et al. (2006). Also Ryll et al. (1997a); Sprenger et al. (1998) reported that airsacculitis, pneumonia and increased mortality were observed after aerosol, intra-tracheal, intravenous and/or intra-thoracic infection.

Nevertheless, not all of the clinical signs and/or postmortem findings that were observed in the natural outbreak could be reproduced experimentally. This discrepancy between natural and experimental $O$. rhinotracheale infection might be explained by differences in aggravating and predisposing factors such as stress, high stock density, poor ventilation, presence of other bacteria, or high ammonia levels in field conditions.

The obtained result in this study indicated obviously variations in pathogenicity of $O$. rhinotracheale among the inoculated routes. Similar conclusions were reported by other researchers (Van Empel et al., 1996 and Travers et al., 1996) they found that the severity of clinical signs and lesions could be referred to route of infection and variations in the virulence and pathogenicity of $O$. rhinotracheale.

In conclusion, our results indicate that $O$. rhinotracheale was isolated by $23.47 \%$ from examined cases of broiler and broiler breeders at Ismailia province. Challenge test suggests that this bacterium was able to produce respiratory signs with various postmortem lesions in experimentally infected chicks and considered as a primary pathogen for chickens.

\section{ACKNOWLEDGMENT}

Authors would like to thanks Dr. Amin A.A. Assis. Prof. Animal Breeding and Genetics Dept. of Animal Prod. Fac. of Agri. Suez Canal Univ. Ismailia Egypt, for his statistical analysis helps in the present study.

\section{REFERENCES}

Abden, S.H. and Lotfy, O.O. (2006): Pathological studies on Ornithobacterium rhinotracheale infection of broilers at sharkia province. Assiut Vet. Med. J. Vol. 52 No. 109 (294304).

Canal, C.W.; Leao, J.A.; Rocha, S.L.; Macagnan, M.; Lima-Rosa, C.A.; Oliveira, S.D. and Back, A. (2005): Isolation and characterization of Ornithobacterium rhinotracheale from chickens in Brazil. Research in Veterinary Science (78) 225230 
Charlton, B.R.; Channing-Santiago, S.E.; Bickford, A.A.; Cardona, C.J.; Chin, R.P.; Cooper, G.L.; Droual, R.; Jeffrey, J.S.; Meteyer, C.U.; Shivaprasad, H.L. and Walker, R.L. (1993): Preliminary characterization of a pleomorphic gram-negative rod associated with avian respiratory disease. J. Vet. Diagn. Invest. 5:47-51. 1993.

CLSI Guidelines (2002): Performance Standards for Antimicrobial Disk and Dilution Susceptibility Tests for Bacteria Isolated from Animals; Approved Standard-Second Edition NCCLS document M31-A2 (pp. 55-59). Pennsylvannia, USA: NCCLS.

Goovaerts, D.; Vrijenhoek, M. and Van Empel, P. (1998): Immuno histochemical and bacteriological investigation of the pathogenesis of Ornithobacterium rhinotracheale infection in South Africa in chickens with osteitis and encephalitis syndrome. In: proc. $16^{\text {th }}$ Meeting of the European society of Veterinary Pathology, Liilehammer, Norway. P. 81

Hafez, H.M.; Kruse, W.; Emele, J. and Sting, R. (1993): Eine Atemwegsinfektion bei Mastputen durch Pasteurella-ähnliche Erreger: Klinik, Diagnostik und Therapie. Proceedings of the International Conference on Poultry Diseases, Potsdam, p:105 112.

Hafez, H.M. (1996): Current status on the role of Ornithobacterium rhinotracheale in respiratory disease complexes in poultry. Arch. Geflügelk. 61: 208-211.

Hafez, H.M. and Schulze, D. (1998): Efficacy of clinical disinfectants on Ornithobacterium rhinotracheale in vitro: Short communication. In Proceedings of the 1st international symposium on turkey diseases, Berlin. (Ed. H.M. Hafez and A. Mazaheri), ISBN 3-930511-53- 3. P: 146-150.

Hafez, M.H. (2002): Diagnosis of Ornithobacterium Rhinotracheale. International Journal of Poultry Science 1(5): 114-118.

Hinz, K.H.; Blome, C. and Ryll, M. (1994): Acute exsudative pneumonia and airsacculitis associated with Ornithobacterium rhinotracheale in turkeys. Veterinary Record 135, 233-234.

Maja, M.; Hans, N.; Luc, D.; An Martell, Koen C.; Devriese, L.; Robrecht, F. and Annemie, D. (2006a): Comparison of the efficacy of four antimicrobial treatment schemes against experimental Ornithobacterium rhinotracheale infection in turkey poults pre-infected with avian pneumovirus. Avian Pathology 35(3), 230-237 
Maja, M.; Annemie, D.; Luc, D.; Chiers, K.; Robrecht, F. and Hans Nauwynck (2006 b): In vivo Selection of Reduced Enrofloxacin Susceptibility in $O$. rhinotracheale and Its Resistance-Related Mutations in gyrA. MICROBIAL DRUG RESISTANCE Volume 12, Number 2, 140-144.

Maja, M.; Annemie, D.; Luc, D.; Chiers, K.; Robrecht, F. and Hans Nauwynck (2007): Efficacy of enrofloxacin, florfenicol and amoxicillin against Ornithobacterium rhinotracheale and Escherichia coli $\mathrm{O} 2: \mathrm{K} 1$ dual infection in turkeys following APV priming. Veterinary Microbiology (121) 94-104.

Malik, Y.S.; Olsen, K.; Kumar, K. and Goyal, S.M. (2003): In vitro antibiotic resistance profiles of Ornithobacterium rhinotracheale strains isolated from Minnesota turkeys during 1996-2002. Avian Dis., 47: 588-593

NCCLS (2002): National Committee for Clinical Laboratory Standards. Performance Standards for Antimicrobial Disk Dilution Susceptibility Tests for Bacteria Isolated from Animals., 2nd ed., NCCLS Approved Standard, Wayne, PA. pp. M31-A2.

Rojs, Z.; Zdovc, O.; Bencina, D. and Mrzel, I. (2000): Infection of turkeys with Ornithobacterium rhinotracheale and Mycoplasma synoviae. Avian Diseases. 44: 1017 - 1022.

Ryll, M.; Hinz, K-H.; Neumann, U.; Lò̀ hren, U.; SuÈ dbeck, M. and Steinhagen, D. (1997b): Pilot study on the prevalence of the Ornithobacterium rhinotracheal e infection in meat-type chickens in Northwest Germany. Berliner und MuÈ nchener TieraÈ rztlichen Wochenschrift, 110, 267-271.

Saeb, N.; El-Sukhon Asad Musa and Majed Al-Attar (2002): Studies on the bacterial etiology of airsacculitis of broilers in Northern and Middle Jordan with special reference to Escherichia coli, Ornithobacterium rhinotracheale and Bordetella avium Avian Diseases. 46: 605-612.

Shahata, M.A.; Abd El-Motelib, T.Y. and Hebat-Allah, A. (2006): some studies on the incidence of Ornithobacterium rhinotracheale infection in chicken embryos and layers._Assiut Vet. Med. J. Vol. 52 No. 110 (243-257).

Shihata, A.B. and Ibraheem, O.K. (2004): Orinthotracheal (ORT) in some birds and rabbit at sharkia Governorate. Proceedings $6^{\text {th }}$ Scientific Conference of the Egyptian Veterinary Poultry Association- Egypt. 288-298. 
Snedecor, G.W. and Cochran, W.G. (1967): Statistical methods $6^{\text {th }}$ Ed. Iowa state Univ. Press.Ames.Iowa

Soriano, V.E.; Longinos, M.G.; Navarrete, P.O. and Fernandez, R.P. (2002): Identification and characterization of Ornithobacterium rhinotracheale isolates from Mexico. Avian Diseases, 46: 686 - 690.

Sprenger, J.; Back, A.; Shaw, P.; Nagaraja, K.; Roepke, D. and Halvorson, D. (1998): Ornithobacterium rhinotracheale infection in turkeys: experimental reproduction of the disease. Avian Diseases, 42, 154-161.

Trovers, A.; Coetzee, L. and Gummow, G. (1996): Pathogenicity differences between South Africa isolates of Omithobacterium rhinotracheale. Onderstepoort Journal of Veterinary Research, 63: 197-207.

Türkyilmaz, S. (2005): Isolation and Serotyping of Ornithobacterium rhinotracheale from Poultry. Turk J Vet Anim. Sci. (29) 12991304

Van Beek P.; Van Empel, P.; Van den Bosch, G.; Storm, P.; Bongers, J. and duPreez, J. (1994): Ademhalingsproblemen, groeivertraging en gewrichtsontsteking bij kalkoenen en vleeskuikens door een Pasteurella-achtige bacterie : Ornithobacterium rhinotracheale of "Taxon 28". Tijdschrift voor Diergeneeskunde 119: 99-101.

Van Empel, P. (1998): Ornithobacterium rhinotracheale. Thesis, University of Utrecht, ISBN 90-393-1574-4.

Van Empel, P. and Hafez, H. (1999): Ornithobacterium rhinotracheale; review. Avian Pathology, 28: 217227.

Van Empel, P.; Van den Bosch, H.; Loeffen, P. and Storm, P. (1997): Identification and serotyping of Ornithobacterium rhinotracheale. J. Clin. Microbiol., 35: 418-421.

Van Veen, L., Gruys, E., Frik, K. and Van Empel, P. (2000a): Increased condemnation of broilers associated with Ornithobacterium rhinotracheale. Vet. Rec. 147: 422-423.

Van Veen, L.; van Empel, P. and Fabria, T. (2000b): Ornithobacterium rhinotracheale, a primary pathogen in broilers. Avian Dis. 44:896-900.

Vandamme, P.; Segers, P.; Vancanney, M.; Van Hove, K.; Mutters, R.; Hommez, J.; Dewhirst, F.; Paster, B.; Kersters, K.; Falsen, E.; Devrise, L.A.; Bisgaard, M.; Hinz, K.H. and Mannheim, W. (1994): Ornithobacterium rhinotracheale gen. nov., sp. nov., 
isolated from the avian respiratory tract. International Journal of Systematic Bacteriology 44, 24-37. 